Available online at http://journal.stkip-andi-matappa.ac.id/index.php/histogram/index

Histogram: Jurnal Pendidikan Matematika ., 2019, 250 - 262

\title{
PENGEMBANGAN PERANGKAT PEMBELAJARAN MATEMATIKA REALISTIK PADA POKOK BAHASAN PECAHAN
}

\author{
Inayanti Fatwa \\ STKIP Pembangunan Indonesia Makassar \\ * Corresponding Author. Email: inayantiazzahra@gmail.com \\ Received: 8 Agustus 2019; Revised: 18 Agustus 2019 ; Accepted: 30 September 2019
}

\begin{abstract}
ABSTRAK
Penelitian ini adalah penelitian pengembangan (Research and Development) yang ujicoba terbatas dilaksanakan di SDN No.1 Centre Pattallassang dengan tujuan untuk menghasilkan perangkat pembelajaran pada pokok bahasan Pecahan di kelas $I V_{A} S D$ dengan pendekatan matematika realistik. Prosedur pengembangan perangkat pembelajaran yang digunakan dalam penelitian ini mengacu pada model Thiagarajan (Model 4-D). Perangkat pembelajaran yang dihasilkan dalam penelitian ini meliputi: Buku Siswa (BS), Lembar Kegiatan Siswa (LKS), Rencana Pelaksanaan Pembelajaran (RPP), dan Tes Hasil Belajar (THB). Perangkat pembelajaran yang dihasilkan telah dilakukan penyempurnaan berdasarkan masukan dan saran dari para ahli yang berkompeten dan ujicoba terbatas di kelas. Adapun hasil dari ujicoba terbatas menunjukkan bahwa: (1) tingkat kemampuan siswa untuk tes hasil belajar pada siswa kelas IV SDN No.1 Centre Pattallassang dalam memahami masalah pecahan dikategorikan tinggi, dengan skor rata-rata 73,60 dari skor maksimal 100 dengan standar deviasi 14,31; (2) dengan menggunakan perangkat pembelajaran matematika realistik, siswa jadi lebih aktif dalam proses pembelajaran; (3) pada umumnya siswa memberikan respons yang positif terhadap perangkat pembelajaran yang digunakan; (4) tingkat kemampuan guru dalam mengelola proses pembelajaran matematika realistik termasuk dalam kategori tinggi, artinya penampilan guru dapat dipertahankan.
\end{abstract}

Kata Kunci: PMR, Perangkat Pembelajaran, Pecahan

How to Cite: Fatwa, I. (2019). Pengembangan Perangkat Pembelajaran Matematika Realistik Pada Pokok Bahasan Pecahan. Histogram: Jurnal Pendidikan Matematika, 3(2), 250 - 262 , doi: http://dx.doi.org/10.31100/histogram.v3i2.553.

Permalink/DOI: http://dx.doi.org/10.31100/histogram.v3i2.553

\section{PENDAHULUAN}

Dengan perkembangan zaman, terdapat perubahan pola pikir pendidik menjadi lebih moderan sehingga dunia pendidikan ikut terus berubah dengan signifikan termasuk kemajuan pendidikan di Indonesia saat ini. Cara menyampaikan konsep dan teori pendidikan menjadi pusat perhatian dari pakar-pakar untuk mencapai tujuan pendidikan yang sesungguhnya.

Tujuan pendidikan untuk menghasilkan sumber daya manusia sebagai subyek dalam pembangunan yang baik sehingga pendidikan merupakan salah satu hal penting untuk menentukan maju mundurnya suatu bangsa. Pada mata pelajaran matematika, prasyarat pemahaman konsep sebelumnya sangatlah penting karena diperlukan untuk memahami konsep yang baru, selain mempunyai sifat yang abstrak. 


\section{Histogram: Jurnal Pendidikan Matematika, 3 (2), 2019 - 251 \\ Inayanti Fatwa}

Matematika adalah suatu pelajaran yang tersusun secara beraturan, logis, berjenjang dari yang paling mudah hingga yang paling rumit. Matematika tersusun sedemikian rupa sehingga konsep terdahulu mendasari konsep berikutnya. Matematika harus dipelajari secara bertahap, berurutan serta berdasarkan kepada pengalaman belajar yang lalu. Seseorang akan mudah mempelajari materi matematika yang baru bila didasarkan pada apa yang telah ia ketahui sebelumnya. Hal ini sejalan dengan pendapat Dienes (Hundojo, 2002) yang menyatakan bahwa: “ Belajar matematika melibatkan suatu struktur hierarki dari konsep-konsep tingkat yang dibentuk atas dasar apa yang telah terbentuk sebelumnya". Belajar matematika adalah suatu usaha atau aktivitas mental untuk memahami arti hubungan dari konsep-konsep dan struktur matematika.

Umumnya kita cuma menerima begitu saja pengajaran matematika di sekolah, tanpa mempertanyakan mengapa atau untuk apa matematika harus diajarkan. Matematika dianggap sebagai momok yang menakutkan dan membuat pusing siswa (dan juga orang tuanya). Begitu beratnya gelar yang disandang matematika yang membuat kekhawatiran pada prestasi belajar matematika siswa. Faktor penyampaian materi atau metode pembelajaran matematika yang monoton dan itu-itu saja merupakan faktor lain yang juga ikut mempengaruhi rasa bosan pada saat belajar matematika.

(Jennings, Sue \& R, 1999) mengatakan umumnya siswa mengalami kesulitan dalam mengaplikasikan matematika ke dalam situasi kehidupan real. Hal lain yang menyebabkan sulitnya matematika bagi siswa adalah karena pembelajaran matematika kurang bermakna. Siswa kurang diberikan kesempatan untuk menemukan kembali dan mengkonstruksi sendiri ide-ide matematika karena guru dalam pembelajarannya di kelas tidak mengaitkan dengan pengalaman kehidupan nyata yang dimiliki oleh siswa. Mengaitkan pengalaman kehidupan nyata siswa dengan ide-ide matematika dalam pembelajaran di kelas penting dilakukan agar pembelajaran bermakna (Price, 1996; Soedjadi, 2000; Zamroni, 2000).

Menurut (Van den Heuvel-Panhuizen, 2000), anak akan cepat lupa dan sulit mengaplikasikan matematika jika anak belajar matematika terpisah dari pengalaman mereka sehari-hari. Oleh karena itu, konsep-konsep matematika dengan pengalaman kehidupan nyata siswa sehari-hari perlu dikaitkan dengan pembelajaran matematika di kelas. Selain itu, perlu menerapkan kembali konsep matematika yang telah dimiliki anak pada kehidupan sehari-hari atau pada bidang lain sangat penting dilakukan.

Salah satu pembelajaran matematika yang berorientasi pada matematisasi pengalaman sehari-hari (mathematize of everyday experience) dan menerapkan matematika 


\section{Histogram: Jurnal Pendidikan Matematika, 3 (2), 2019 - 252 \\ Inayanti Fatwa}

dalam kehidupan sehari-hari adalah pembelajaran Matematika Realistik (MR). Pembelajaran Matematika Realistik merupakan teori belajar mengajar dalam pendidikan matematika yang diperkenalkan dan dikembangkan di Belanda pada tahun 1970 oleh Institut Freudenthal. Teori ini mengacu pada pendapat Freudenthal yang mengatakan bahwa matematika harus dikaitkan dengan dunia nyata dan matematika merupakan aktivitas manusia.

Pembelajaran matematika realistik mengakibatkan siswa aktif dalam proses pembelajaran di kelas. Pada awal pembelajaran di kelas, guru hanya berperan sebagai pembimbing dalam memilih kontribusi-kontribusi yang diberikan siswa melalui pemecahan masalah kontekstual.

Salah satu materi matematika yang banyak digunakan dalam kehidupan sehari-hari adalah pecahan yang diajarkan di SD kelas IV. Untuk meningkatkan pemahaman dan penguasaan siswa terhadap materi tersebut, maka penerapan pendekatan pembelajaran matematika realistik dalam pembelajaran matematika di sekolah, karena pembelajaran dengan pendekatan realistik didesain berawal dari pemecahan masalah yang berada di sekitar siswa dan berbasis pengetahuan yang telah dimiliki siswa.

Untuk melaksanakan pembelajaran matematika dengan pendekatan realistik, diperlukan perangkat yang sesuai dengan pendekatan tersebut. Mengingat pembelajaran matematika realistik berorientasi pada matematisasi pengalaman sehari-hari dan menerapkan matematika dalam kehidupan sehari-hari. Oleh karena itu, penulis termotivasi untuk melakukan penelitian dengan judul "Pengembangan Perangkat Pembelajaran Matematika Realistik pada Pokok Bahasan Pecahan Siswa Kelas $I_{A} S D N$ No. 1 Centre Pattallassang”. Berdasarkan uraian latar belakang di atas, maka rumusan masalah dalam penelitian ini adalah "Bagaimana mengembangkan perangkat pembelajaran matematika realistik pada pokok bahasan Pecahan siswa kelas $I V_{A}$ di SDN No. 1 Centre Pattallassang? Adapun tujuan yang ingin dicapai dalam penelitian ini adalah untuk menghasilkan perangkat pembelajaran matematika realistik pada pokok bahasan pecahan siswa kelas $\mathrm{IV}_{\mathrm{A}}$ SDN No. 1 Centre Pattallassang.

\section{METODE PENELITIAN}

\section{A. Tempat dan Waktu}

Penelitian ini dilaksanakan di SDN No. 1 Centre Pattallassang Kabupaten Takalar, Sulawesi Selatan. Tahun ajaran 2009/2010, dan sebagai subjek penelitiannya adalah siswa kelas $\mathrm{IV}_{\mathrm{A}}$ 


\section{Histogram: Jurnal Pendidikan Matematika, 3 (2), 2019 - 253 \\ Inayanti Fatwa}

\section{B. Survei Pendahuluan}

Penelitian ini dilaksanakan pada semester genap tahun ajaran 2009/2010. Dengan tiga tahap yaitu tahap persiapan, tahap pelaksanaan, dan tahap analisis data. 1. Tahap persiapan

Kegiatan yang dilakukan pada tahap ini adalah : 1) Menelaah kurikulum SD kelas IV semester genap untuk pelajaran matematika; 2) Mengembangkan perangkat pembelajaran yaitu buku siswa, lembar kegiatan siswa, rencana pelaksanaan pembelajaran, dan tes hasil belajar siswa; 3) Membuat lembar observasi untuk mengamati aktivitas siswa, aktivitas guru, dan pengelolaan pembelajaran di kelas; 4) Membuat angket untuk mengetahui respon siswa tentang perangkat pembelajaran yang dikembangkan dengan pendekatan matematika realistik.

2. Tahap pelaksanaan

Kegiatan yang dilakukan pada tahap ini adalah: 1) Membagi kelompok secara random; 2) Melaksanakan pembelajaran matematika realistik; 3) Selama proses pembelajaran berlangsung dilakukan pengamatan aktivitas siswa, dan kemampuan guru mengelola pembelajaran yang dilakukan oleh satu orang pengamat.

3. Tahap analisis data

Kegiatan pada tahap ini adalah menganalisis data yang diperoleh dari tahap pelaksanaan. Data-data yang akan dianalisis adalah data hasil belajar siswa, data hasil pengamatan aktivitas siswa dan aktivitas guru, dan data hasil pengamatan pengelolaan pembelajaran.

a. Variabel yang diukur

Variabel yang diukur berupa instrumen pengumpul data yang digunakan dalam penelitian.

\section{Tahap pelaksanaan /Rancangan Penelitian}

1. Prosedur Pengembangan Perangkat Pembelajaran Matematika

Pengembangan perangkat pembelajaran matematika yang digunakan mengacu pada model 4-D atau model Thiagarajan. Model ini merupakan sistem pendekatan pengembangan pembelajaran yang dilakukan meliputi 4 tahap yaitu pendefinisian, perancangan, pengembangan dan pendiseminasian. Prosedur pengembangan perangkat pembelajaran yang dilalui dalam penelitian ini dapat dijelaskan sebagai berikut:

a. Tahap Pendefenisian 


\section{Histogram: Jurnal Pendidikan Matematika, 3 (2), 2019 - 254 \\ Inayanti Fatwa}

Tahap ini bertujuan untuk menentukan dan mendefinisikan syarat-syarat yang dibutuhkan dalam pembelajaran dengan menganalisis tujuan dan batasan materi. Kegiatan yang dilakukan pada tahap ini adalah analisis awal-akhir (analisis kurikulum), analisis peserta didik (siswa), analisis konsep, analisis tugas, dan spesifikasi tujuan pembelajaran.

b. Tahap Perancangan

Tahap ini bertujuan untuk menghasilkan rancangan perangkat pembelajaran untuk SD kelas IV pada pokok bahasan Pecahan. Kegiatan pada tahap ini adalah kriteria pemilihan media, pemilihan format, dan perancangan awal perangkat pembelajaran yang dimulai setelah ditetapkan tujuan pembelajaran khusus.

Adapun rancangan awal perangkat pembelajaran tersebut meliputi Buku Siswa, Lembar Kegiatan Siswa (LKS), Rencana Pelaksanaan Pembelajaran (RPP), dan Tes Hasil Belajar (THB). Semua perangkat pembelajaran yang dihasilkan pada tahap ini disebut dengan perangkat pembelajaran draft I.

c. Tahap Pengembangan

Tahap pengembangan ini bertujuan untuk mendapatkan draft perangkat pembelajaran yang telah direvisi berdasarkan masukan para ahli, sehingga diperoleh perangkat pembelajaran draft II dan data yang diperoleh dari ujicoba yang bersifat terbatas yaitu hanya dilakukan satu kali terbatas pada satu kelas. Hal ini bertujuan untuk mendapatkan masukan atau saran dari siswa dan guru di lapangan dalam rangka untuk merevisi perangkat pembelajaran draft II. Pelaksanaan ujicoba meliputi pelaksanaan proses pembelajaran dan pemberian tes hasil belajar. Hasil ujicoba dianalisis dan digunakan sebagai bahan pertimbangan untuk merevisi perangkat pembelajaran draft II sehingga diperoleh perangkat pembelajaran draft III.

Hasil ujicoba terbatas yang telah direvisi, selanjutnya divalidasi kembali oleh validator untuk mendapatkan perangkat pembelajaran akhir yang disebut dengan draft IV sebagai draft final.

d. Tahap Pendiseminasian

Tahap pendiseminasian belum dapat dilakukan karena dalam penelitian ini hanya ujicoba terbatas yang dilakukan.

2. Instrumen Pengumpulan Data

Adapun instrumen pengumpul data yang digunakan dalam penelitian ini adalah sebagai berikut:

a. Lembar Pengamatan Aktivitas Siswa

b. Lembar Pengamatan Aktivitas Guru 


\section{Histogram: Jurnal Pendidikan Matematika, 3 (2), 2019 - 255 \\ Inayanti Fatwa}

c. Lembar Pengamatan Pengelolaan Pembelajaran Matematika Realistik

d. Respon Siswa terhadap Kegiatan pembelajaran

e. Tes Hasil Belajar

3. Metode Pengumpulan Data

Metode pengumpulan data pengembangan yang dilakukan dalam penelitian ini adalah data hasil validasi ahli, data dokumentasi, data tes hasil belajar, data keaktifan siswa dan guru, data pengelolaan pembelajaran.

4. Analisis Data

Data dianalisis secara kuantitatif dan diarahkan untuk menjelaskan kevalidan, keefektifan dan kepraktisan perangkat pembelajaran dengan pendekatan realistik yang tengah dikembangkan. Data yang diperoleh dari hasil validasi oleh para ahli dianalisis untuk menjelaskan kevalidan sehingga dapat dinyatakan layak digunakan perangkat pembelajaran dengan pendekatan realistik di kelas. Adapun data hasil coba di kelas digunakan untuk menjelaskan keefektifan dan kepraktisan perangkat pembelajaran dengan pendekatan realistik setting kooperatif (Darwis, 2007).

\section{HASIL DAN PEMBAHASAN}

\section{A. Hasil Penelitian}

Pengembangan perangkat pembelajaran matematika realistik berdasarkan model 4-D atau model Thiagarajan terdiri atas empat tahap. Pada penelitian ini kegiatan-kegiatan yang dilakukan meliputi tahap pendefinisian (define), tahap perancangan (design), dan tahap pengembangan (develop).

1. Deskripsi Tahap Pendefinisian

a. Analisis Awal-Akhir

Berdasarkan hasil telaah terhadap pelaksanaan dan hasil pembelajaran matematika di SDN No.1 Centre Pattallassang adalah cukup memuaskan prestasi belajar matematika yang dicapai siswa. Proses pembelajaran di kelas $\mathrm{IV}_{\mathrm{A}}$ SDN No.1 Centre Pattallassang cenderung memberikan kesempatan yang cukup kepada siswa untuk mengembangkan kemampuannya sendiri. Sebagian siswa cukup rajin bertanya apalagi mengemukakan jalan pikiran atau pendapatnya tentang materi yang sedang dipelajari. Proses pembelajaran lebih banyak didominasi oleh guru sementara siswa hanya mendengarkan dan mencatat apa yang disampaikan oleh guru serta terkadang melakukan kegiatan yang tidak berhubungan dengan pembelajaran misalnya melamun dan ke luar kelas. Berdasarkan analisis awal-akhir peneliti tertarik untuk mengembangkan perangkat pembelajaran matematika realistik dengan model pembelajaran kooperatif. 


\section{Histogram: Jurnal Pendidikan Matematika, 3 (2), 2019 - 256 \\ Inayanti Fatwa}

\section{b. Analisis Siswa}

Pada tahap ini, penulis menemukan bahwa siswa kelas IV $\mathrm{A}$ SDN No.1 Centre Pattallassang sudah mempelajari materi Pecahan di kelas III Sekolah Dasar. Walaupun demikian guru masih perlu mengingatkan kembali materi tersebut di awal pertemuan. Siswa kelas $\mathrm{IV}_{\mathrm{A}}$ SDN No.1 Centre Pattallassang dalam pembelajaran menggunakan Bahasa Indonesia. Mereka masih memerlukan benda-benda konkret dalam pembelajaran matematika. Oleh karena itu, sangat tepat bila pembelajaran matematika diawali dengan masalah kontekstual yang dekat dengan kehidupan sehari-hari siswa.

c. Analisis Konsep

Konsep utama yang diidentifikasi pada pengembangan perangkat pembelajaran ini adalah analisis konsep untuk materi pecahan.

d. Analisis Tugas

Analisis tugas berdasarkan pokok bahasan Pecahan diperoleh beberapa tugas-tugas yang mengarahkan kemampuan siswa untuk menjawab tugas-tugas sehingga tujuan pembelajaran dapat tercapai.

e. Spesifikasi Tujuan Pembelajaran

Berdasarkan analisis konsep dan analisis tugas pada materi pecahan, maka tujuan pembelajaran didasarkan atas indikator pencapaian dan tujuan pembelajaran yang sesuai dengan kurikulum yang dipakai sebagai acuan.

2. Deskripsi Tahap Perancangan

a. Pemilihan Media

Media pembelajaran yang diperlukan dalam pelaksanaan pembelajaran matematika realistik pada pokok bahasan pecahan di kelas IV SD adalah perangkat pembelajaran yang meliputi: Buku Siswa (BS), Lembar Kegiatan Siswa (LKS), Rencana Pelaksanaan Pembelajaran (RPP), dan Tes Hasil Belajar Siswa (THB).

\section{b. Pemilihan Format}

Pemilihan format dalam pengembangan perangkat pembelajaran meliputi: isi materi adalah pecahan, model pembelajaran yang digunakan adalah kooperatif, dengan media pembelajaran buku siswa, LKS, dan RPP yang mengacu pada Kurikulum Tingkat Satuan Pendidikan (KTSP). Dalam Rencana Pelaksanaan Pembelajaran tercantum standar kompetensi, kompetensi dasar, indikator pencapaian kompetensi dasar, materi pembelajaran, pemilihan dan pengorganisasian materi ajar, sumber belajar, kegiatan 


\section{Histogram: Jurnal Pendidikan Matematika, 3 (2), 2019 - 257 \\ Inayanti Fatwa}

pembelajaran, alat/bahan dan sumber pembelajaran, langkah-langkah kegiatan, dan penilaian. Format Buku Siswa dan LKS dibuat semenarik mungkin dan dilengkapi dengan soal-soal sehingga siswa akan tertarik dan termotivasi untuk belajar.

c. Perancangan Awal

Kegiatan utama dalam tahap akhir kegiatan perancangan adalah penyusunan perangkat pembelajaran pokok bahasan pecahan untuk SD kelas IV yang meliputi Buku Siswa (BS), Lembar kegiatan Siswa (LKS), Rencana Pelaksanaan Pembelajaran (RPP), dan Tes Hasil Belajar (THB). Pada tahap ini dihasilkan rancangan awal Rencana Pelaksanaan Pembelajaran (RPP) untuk 5 kali pertemuan, Buku Siswa untuk setiap pertemuan, LKS untuk setiap pertemuan, dan Tes Hasil Belajar beserta kisi-kisi dan kunci jawaban. Semua hasil perangkat pembelajaran pada tahap perancangan ini disebut draft I.

3. Deskripsi Tahap Pengembangan

a. Penilaian Para Ahli

Secara umum, hasil penilaian para ahli terhadap perangkat pembelajaran yang meliputi Buku Siswa, LKS, dan RPP dapat di lihat pada tabel berikut:

Tabel 1. Rangkuman Hasil Validasi Perangkat Pembelajaran

\begin{tabular}{lcc}
\hline \multicolumn{1}{c}{ Sumber } & $\begin{array}{c}\text { Skor Rata-rata } \\
\text { Penilaian }\end{array}$ & Kriteria \\
\hline Buku Siswa & 3,62 & Valid \\
\hline Lembar Kegiatan Siswa & 4,06 & Valid \\
\hline Rencana Pelaksanaan Pembelajaran & 4,01 & Valid \\
\hline
\end{tabular}

(Sumber: Data Primer, Tahun: 2010)

Berdasarkan tabel 1, dapat disimpulkan bahwa rata-rata penilaian atau hasil validasi dari para ahli pada perangkat pembelajaran yang dikembangkan yang meliputi Buku Siswa dan LKS, dan RPP berada pada kategori "Valid" $(3,5 \leq \bar{X}<4,50)$. Namun demikian perangkat- perangkat tersebut yang menurut saran para ahli masih perlu diperbaiki atau ditambahkan. Hal ini berarti perangkat pembelajaran tersebut telah layak untuk diujicobakan.

Revisi yang dilakukan pada setiap perangkat pada umumnya terletak pada kesalahan tata bahasa dan kesalahan penulisan. Sementara untuk rencana pelaksanaan pembelajaran, langkah-langkah pembelajaran dibuat berdasarkan pembelajaran matematika realistik. 


\section{Histogram: Jurnal Pendidikan Matematika, 3 (2), 2019 - 258 \\ Inayanti Fatwa}

b. Ujicoba

Draft I yang telah direvisi berdasarkan saran dan masukan dari para ahli, selanjutnya disebut draft II, diujicobakan pada siswa kelas IV SDN No.1Centre Pattallassang. Pada kegiatan ini penulis memberikan tes hasil belajar sebanyak dua kali untuk mengetahui tingkat penguasaan siswa untuk satu indikator dan dua indikator.

Berdasarkan hasil ujicoba di lapangan, skala penilaian Tes Hasil Belajar dapat digunakan dengan tanpa revisi. Perangkat yang telah direvisi berdasarkan hasil uji coba tersebut disebut Draft III sekaligus sebagai Draft Akhir.

\section{B. Analisis Deskriptif Hasil Penelitian}

Berdasarkan hasil ujicoba perangkat pembelajaran yang meliputi buku siswa, LKS, dan RPP diperoleh data hasil tes belajar siswa, data hasil pengamatan aktivitas siswa, respons siswa terhadap kegiatan dan perangkat pembelajaran dengan pendekatan realistik, data hasil pengamatan aktivitas guru, dan data hasil pengamatan pengelolaan pembelajaran dengan pendekatan realistik. Data-data inilah yang digunakan untuk mengetahui keefektifan dan kepraktisan perangkat pembelajaran dengan pendekatan realistik. Hasil analisis masing-masing data sebagai berikut:

1. Data Hasil Tes Belajar Siswa

Tes hasil belajar diberikan ke siswa untuk memperoleh informasi tentang penguasaan siswa terhadap materi yang telah diajarkan. Hasil analisis deskriptif secara kuantitatif penguasaan matematika setelah diberi tindakan pada tes hasil belajar dapat dilihat pada tabel berikut:

Tabel 2. Statistik skor hasil belajar matematika siswa kelas $\mathrm{IV}_{\mathrm{A}} \mathrm{SDN}_{\mathrm{S}}$. 1 Centre Pattallassang

\begin{tabular}{cc}
\hline Variabel & Nilai Statistik \\
\hline Subjek Penelitian & 35 \\
\hline Skor Ideal & 100 \\
\hline Rata-rata & 73,60 \\
\hline Standar Deviasi & 14,31 \\
\hline Varians & 204,78 \\
\hline Rentang Skor & 50 \\
\hline Skor Maksimum & 97 \\
\hline Skor Minimum & 47 \\
\hline Jumlah Siswa yang Tuntas & 30 \\
\hline
\end{tabular}




\section{Histogram: Jurnal Pendidikan Matematika, 3 (2), 2019 - 259 \\ Inayanti Fatwa}

\begin{tabular}{cc}
\hline Variabel & Nilai Statistik \\
\hline Jumlah Siswa yang Tidak Tuntas & 5
\end{tabular}

(Sumber: Data Primer, Tahun: 2010)

Pada tabel 2 menunjukkan bahwa hasil belajar siswa kelas IV $_{\mathrm{A}}$ SDN No. 1 Centre Pattallassang terhadap pelajaran matematika diperoleh skor rata-rata 73,60 dari skor ideal 100 dengan standar deviasi 14,31. Skor minimum yang diperoleh siswa adalah 47 dan skor maksimum yang diperoleh siswa adalah 97 dengan rentang skor 50 .

Jika skor hasil belajar dikelompokkan dalam lima kategori, maka diperoleh hasil bahwa dari 35 siswa yang mengikuti tes hasil belajar terdapat $0,00 \%$ siswa masuk dalam kategori sangat rendah, 5,70\% siswa masuk dalam kategori rendah, 25,70\% siswa masuk dalam kategori sedang, 40,00\% masuk dalam kategori tinggi, sedangkan siswa yang masuk dalam kategori sangat tinggi adalah 28,60\%. Hal ini menunjukkan bahwa siswa memperoleh pemahaman yang bervariasi terhadap materi yang disajikan dengan menggunakan perangkat pembelajaran dengan pendekatan realistik. Namun dari data tersebut dapat diketahui bahwa pemahaman siswa cenderung tinggi atau sangat tinggi.

Tabel 2 juga menunjukkan bahwa banyaknya siswa yang tuntas belajar atau yang mencapai ketuntasan hasil belajar individu yaitu siswa yang memperoleh skor $60-100$ sebanyak 30 orang dari 35 orang siswa atau sekitar $85,70 \%$. Jadi banyaknya siswa yang belum tuntas, yaitu siswa yang memperoleh skor $0-59$, sebanyak 5 orang dari 35 orang siswa atau sekitar 14,30 \%. Data ini menunjukkan bahwa ketuntasan klasikal tercapai.

2. Data Hasil Pengamatan Aktivitas Siswa

Hasil pengamatan aktivitas siswa diketahui bahwa semua kategori aktivitas siswa yang diamati ternyata memenuhi Interval Toleransi PWI (\%). Artinya, kriteria pencapaian waktu ideal aktivitas siswa yang telah tercapai, yaitu 5 dari 9 kategori terpenuhi dan syarat utama yaitu kategori (3), (4), (7), dan (8) terpenuhi yakni aktif terlibat dalam tugas, aktif berdiskusi dengan teman, menjawab/menanggapi pertanyaan teman/guru, dan memberi bantuan penjelasan kepada teman yang membutuhkan merupakan syarat utama dari kategori yang terpenuhi.

3. Respons Siswa terhadap Kegiatan Pembelajaran dengan Pendekatan Realistik

Respons siswa terhadap kegiatan pembelajaran dengan pendekatan realistik berdasarkan angket yang diberikan ke siswa sebagai berikut:

a. Respons Siswa tentang Pelajaran Matematika 


\section{Histogram: Jurnal Pendidikan Matematika, 3 (2), 2019 - 260 \\ Inayanti Fatwa}

Respons siswa terhadap pelajaran matematika bervariasi, mulai yang merasa bahwa matematika itu menyenangkan hingga merasa bahwa matematika itu gampanggampang susah, sangat sulit dan menarik. Dari 35 siswa, 26 siswa $(74,29 \%)$ diantaranya merasa senang dengan pelajaran matematika, bahkan menjadi pelajaran kesukaan mereka dibandingkan dengan pelajaran yang lain. Dari hasil observasi juga diketahui bahwa 6 dari 35 siswa $(17,14 \%)$ yang menyatakan bahwa matematika itu kadang susah kadang mudah, bahkan 3 dari 35 siswa $(8,57 \%)$ menyatakan matematika itu mudah. Mereka beralasan bahwa pelajaran matematika cuma menyangkut masalah penjumlahan, pengurangan, perkalian, dan pembagian. Apalagi dengan adanya pembelajaran dengan pendekatan realistik, mereka semakin menyukai pelajaran matematika.

b. Respons Siswa tentang Buku Siswa dan LKS

30 dari 35 siswa $(85,71 \%)$ merasa senang dengan buku siswa dan LKS yang digunakan. Mereka beralasan bahwa penggunaan kata-kata/penjelasan materi dan gambargambar yang terdapat pada buku siswa dan LKS cukup sederhana dan menarik sehingga memudahkan mereka untuk mengerti materi yang disajikan apalagi disertai dengan gambar-gambar yang menyangkut dengan soal. Dari hasil observasi juga diketahui bahwa 4 dari 35 siswa $(11,43 \%)$ berpendapat bahwa ada beberapa bahasa yang digunakan dalam buku siswa atau LKS yang tidak terlalu jelas sehingga terkadang tidak mereka mengerti. Dan 1 dari 35 siswa $(2,86 \%)$ tidak memberikan komentar. Namun demikian secara keseluruhan, siswa tertarik dengan buku siswa dan LKS yang digunakan.

c. Respons Siswa tentang Pembelajaran dengan Pendekatan Realistik

26 dari 35 siswa $(74,29 \%)$ senang dengan pembelajaran melalui pendekatan realistik. Mereka beralasan bahwa penyajian materi yang dikaitkan dengan dunia nyata memudahkan mereka untuk memahami dengan mudah materi tersebut. Namun demikian, 9 dari 35 siswa $(25,71 \%)$ tidak memberikan komentar, mereka hanya memaparkan contoh soal mengenai pembelajaran realistik. Maka dapat disimpulkan bahwa siswa memiliki respons positif terhadap perangkat pembelajaran dengan pendekatan realistik.

\section{Data Hasil Pengamatan Aktivitas Guru}

Data hasil pengamatan aktifitas guru diketahui bahwa semua kategori aktivitas guru yang diamati memenuhi Interval Toleransi PWI (\%). Artinya, kriteria pencapaian waktu ideal aktivitas guru telah dibahas tercapai, yaitu kategori (2), (4), (5), (6) dan (7) terpenuhi yakni kategori meminta siswa mengerjakan tugas LKS dengan kerjasama dalam 


\section{Histogram: Jurnal Pendidikan Matematika, 3 (2), 2019 - 261 \\ Inayanti Fatwa}

kelompok, mengontrol/berkeliling memperhatikan kerja kelompok, membimbing/memberi bantuan kepada siswa dalam aktivitas siswa kelompok, mengajukan pertanyaan yang merangsang berfikir siswa (pertanyaan yang membuka wawasan), memberi umpan balik yang merupakan syarat utama dari kategori-kategori tersebut terpenuhi.

5. Data Hasil Pengamatan Pengelolaan Pembelajaran dengan Pendekatan Realistik Setting Kooperatif

Berdasarkan kriteria keefektifan yang telah dibahas, maka dapat disimpulkan bahwa perangkat pembelajaran dengan pendekatan realistik bersifat efektif, dimana semua komponen keefektifan perangkat terpenuhi dan komponen (1) yaitu ketuntasan klasikal yang menjadi syarat utama terpenuhi.

Selain itu, dapat disimpulkan pula bahwa perangkat pembelajaran dengan pendekatan realistik setting kooperatif bersifat praktis, dimana semua komponen kepraktisan perangkat terpenuhi.

\section{Pembahasan}

Perangkat pembelajaran yang meliputi buku siswa, LKS, RPP, dan THB ini valid, Hal ini didukung oleh penelitian (Arif, 2013; Marhama, Zulkardi, \& Aisyah, 2011) yang menunjukkan bahwa Perangkat Pembelajaran Matematika Realistik Setting Kooperatif tipe STAD ditinjau dari keseluruhan aspek dapat dinyatakan valid.

Siswa memperoleh pemahaman yang cenderung tinggi atau sangat tinggi terhadap materi pecahan yang disajikan dengan menggunakan perangkat pembelajaran dengan pendekatan realistik . Hal ini didukung oleh penelitian (Arif, 2013; Hikmah, 2017) yang menyimpulkan bahwa hasil tes belajar matematika berada pada kategori tinggi. Hal ini disebabkan pengetahuan yang diperoleh siswa dengan pendekatan realistik dapat tersimpan dalam memori jangka panjang, sehingga pengetahuan tersebut tidak mudah dilupakan (Arif, 2013).

Siswa memiliki respons positif terhadap perangkat pembelajaran dengan pendekatan realistik. Hal ini didukung oleh hasil penelitian (Arif, 2013) menunjukkan bahwa rata-rata respon positif siswa terhadap keseluruhan perangkat sebesar 95,8\%. Hal ini dikarenakan materi ajar dilengkapi dengan gambar-gambar realistik, soal-soal yang disajikan menyangkut masalah kehidupan sehari-hari dan mereka dapat berinteraksi dan berbagi tugas dalam kelompoknya (Arif, 2013).

Tingkat kemampuan guru dalam mengelola proses pembelajaran matematika realistik termasuk dalam kategori tinggi. Hal ini didukung oleh hasil penelitian (Arif, 2013; Hikmah, 2017) yang menunjukkan kemampuan guru mengelola pembelajaran minimal 


\section{Histogram: Jurnal Pendidikan Matematika, 3 (2), 2019 - 262 \\ Inayanti Fatwa}

tinggi. Hal ini disebabkan oleh RPP dalam perangkat pembelajaran Matematika Realistik ini memiliki sintaks dan rincian waktu yang jelas setiap kegiatan, ada sub fase memahami masalah, bertanya, berdiskusi dan siswa mengkonstruksi ide-ide matematika dengan bantuan secara scaffolding baik oleh teman sekelompoknya maupun dari guru (Arif, 2013).

\section{KESIMPULAN DAN SARAN}

\section{A. Kesimpulan}

Berdasarkan hasil penelitian dan pembahasan ujicoba terbatas terhadap siswa kelas IV $_{\mathrm{A}}$ SDN No.1 Centre Pattallassang, diperoleh kesimpulan sebagai berikut: 1) Perangkat pembelajaran matematika realistik pada pokok bahasan Pecahan dalam penelitian ini meliputi: a) Buku siswa (BS); b) Lembar Kegiatan Siswa (LKS); c) Rencana Pelaksanaan Pembelajaran (RPP), dan Tes Hasil Belajar (THB); 2) Pengembangan perangkat ini menggunakan model Thiagarajan atau 4-D (Define, Design, Develop, dan Disseminate) yang meliputi empat tahap yaitu tahap pembatasan, tahap perancangan, tahap pengembangan, dan tahap penyebaran; 3) Setelah dilakukan validasi dan revisi sebanyak 2 kali, perangkat pembelajaran yang meliputi buku siswa, LKS, RPP, dan THB ini valid sehingga layak untuk digunakan berdasarkan hasil penilaian para ahli; 4) Dari hasil ujicoba diketahui bahwa perangkat pembelajaran matematika realistik bersifat efektif dan praktis, hasil ujicoba diuraikan sebagai berikut: a) Skor rata-rata yang diperoleh siswa pada tes hasil belajar adalah 73,60 dari skor ideal 100 dengan standar deviasi 14,31. Dimana 30 dari 35 siswa atau 85,70 \% memenuhi ketuntasan hasil belajar individu. Data ini menunjukkan bahwa ketuntasan klasikal tercapai; b) Dengan menggunakan perangkat pembelajaran matematika realistik, siswa jadi lebih aktif dalam proses pembelajaran; c) Pada umumnya siswa memberikan respons yang positif terhadap perangkat pembelajaran yang digunakan; d) Guru dapat membimbing kelompok bekerja dan belajar berdasar dari 5 dari 8 kategori aktivitas guru yang diamati terpenuhi; e) Tingkat kemampuan guru dalam mengelola proses pembelajaran matematika realistik termasuk dalam kategori tinggi, artinya penampilan guru dapat dipertahankan.

\section{B. Saran}

Adapun Saran dari penelitian ini adalah : 1) Perangkat pembelajaran yang telah dihasilkan sebaiknya diujicobakan di sekolah-sekolah lain; 2) Pengembangan perangkat pembelajaran matematika realistik sebaiknya dikembangkan pada pokok bahasan lain agar semakin menumbuhkan minat dan motivasi siswa untuk belajar matematika dengan 


\section{Histogram: Jurnal Pendidikan Matematika, 3 (2), 2019 - 263 Inayanti Fatwa}

melakukan ujicoba berkali-berkali sehingga didapatkan perangkat pembelajaran matematika yang layak untuk digunakan dan dilakukan sampai pada tahap penyebaran.

\section{DAFTAR PUSTAKA}

Arif, S. (2013). The Development Of Mathematics Learning Instrument By Using Realistic Setting Cooperative Stad Type For Basic Competence Of Fraction Number. Jurnal Daya Matematis, 1(2), 223-233.

Darwis, M. (2007). Model Pembelajaran Matematika yang Melibatkan Kecerdasan Emosional. Universitas Negeri Surabaya.

Hikmah. (2017). Pengembangan Perangkat Pembelajaran Matematika Realistik pada Siswa Kelas V SD. Jurnal Saintifik, 3(1), 24-30.

Hundojo, H. (2002). Pengembangan Kurikulum dan Pembelajaran Matematika. Malang: UM Press.

Jennings, Sue \& R, D. (1999). Math Stories, Real Stories, Real-life Stories.

Marhama, Zulkardi, \& Aisyah, N. (2011). Pengembangan Materi Ajar Pecahan Dengan Pendekatan PMRI Di SD Negeri 21 Palembang. Jurnal Pendidikan Matematika, 5(2), $171-184$.

Price, J. (1996). "President's Report : Bulding Bridges of Mathematical Understanding for All Children." In Journal for Research in Mathematics Education. Vol.27. No.5 November 1996 (pp. 603-608). NCTM.

Soedjadi, R. (2000). Kiat pendidikan matematika di Indonesia: konstatasi keadaan masa kini menuju harapan masa depan. Jakarta: Direktorat Jenderal Pendidikan Tinggi, Departemen Pendidikan Nasional.

Van den Heuvel-Panhuizen, M. (2000). Mathematics education in the Netherlands: A guided tour. In Freudenthal Institute CD-Rom for ICME9. Utrecht: Utrecht University.

Zamroni. (2000). Paradigma Pendidikan Masa Depan. Yogyakarta: Bigraf Publishing. 